Check for updates

Cite this: RSC Adv., 2019, 9, 15424

Received 16th March 2019

Accepted 9th May 2019

DOI: $10.1039 / c 9 r a 02028 d$

rsc.li/rsc-advances

\section{Experimental and computational investigation of a DNA-shielded 3D metal-organic framework for the prompt dual sensing of $\mathrm{Ag}^{+}$and $\mathrm{S}^{2-} \dagger$}

\author{
Shao-Lan Cai, Zi-Chuan Yang, Ke-Yang Wu, Cheng Fan, Ling-Yan Zhai, \\ Nai-Han Huang, Rong-Tian Li, Wen-Jun Duan* and Jin-Xiang Chen (D)*
}

\begin{abstract}
We herein report an efficient $\mathrm{Ag}^{+}$and $\mathrm{S}^{2-}$ dual sensing scenario by a three-dimensional (3D) Cu-based metalorganic framework $\left[\mathrm{Cu}(\mathrm{Cdcbp})(\text { (bpea) }]_{n}\right.$ (MOF 1, $\mathrm{H}_{3} \mathrm{CdcbpBr}=3$-carboxyl-(3,5-dicarboxybenzyl)-pyridinium bromide, bpea =1,2-di(4-pyridinyl)ethane) shielded with a 5-carboxytetramethylrhodamine (TAMRA)-labeled Crich single-stranded DNA (ss-probe DNA, P-DNA) as a fluorescent probe. The formed MOF-DNA probe, denoted as P-DNA@1, is able to sequentially detect $\mathrm{Ag}^{+}$and $\mathrm{S}^{2-}$ in one pot, with detection limits of $3.8 \mathrm{nM}$ (for $\mathrm{Ag}^{+}$) and $5.5 \mathrm{nM}$ (for $\mathrm{S}^{2-}$ ), which are much more lower than the allowable $\mathrm{Ag}^{+}(0.5 \mu \mathrm{M})$ and $\mathrm{S}^{2-}(0.6 \mu \mathrm{M})$ concentration in drinking water as regulated by World Health Organization (WHO). The detection method has been successfully applied to sense $\mathrm{Ag}^{+}$and $\mathrm{S}^{2-}$ in domestic, lake, and mineral water with satisfactory recoveries ranging from 98.2 to $107.3 \%$. The detection mechanism was further confirmed by molecular simulation studies.
\end{abstract}

\section{Introduction}

Silver ions $\left(\mathrm{Ag}^{+}\right)$are ubiquitous and widely applied in various fields including biomedicine, antibacterial manufacturing, etc. $^{1}$

Guangdong Provincial Key Laboratory of New Drug Screening, School of Pharmaceutical Sciences, Southern Medical University, Guangzhou 510515, P. R. China.E-mail: jxchen@smu.edu.cn; wjduan@smu.edu.cn; Fax:+86-20-61648533

$\dagger$ Electronic supplementary information (ESI) available: General, X-ray crystal structure determinations, $\mathrm{Ag}^{+}$and $\mathrm{S}^{2-}$ detection experiments, computational molecular simulation studies, crystallographic data, selected bond distances ( $\AA$ ) and angles $\left({ }^{\circ}\right)$ for $\mathbf{1}$, the analytical performance of various $\mathrm{Ag}^{+}$sensors, comparison of different sensing platforms for $\mathrm{S}^{2-}$ detection, the single point energy results of P-DNA, P-DNA@1, ds-DNA@Ag ${ }^{+}$and 1 + ds-DNA@Ag ${ }^{+}$, detection of $\mathrm{Ag}^{+}$and $\mathrm{S}^{2-}$ in environmental water samples, PXRD patterns of MOF 1 showing agreement among the simulated, as-synthesized and fresh powder of MOF 1 immerse in Hepes buffer $(20 \mathrm{mM}, \mathrm{pH}=6.5,7.0,7.4)$ for $24 \mathrm{~h}$ respectively, the SEM image of MOF 1 , comparison of the intensity of the emission peak $(582 \mathrm{~nm})$ of the P-DNA in $20 \mathrm{mM}$ Hepes buffer $(\mathrm{pH}=6.5,7.0$, 7.4) for $4 \mathrm{~h}$, the fluorescence quenching of the P-DNA (50 nM) incubated with MOF 1 with increasing concentrations in Hepes buffer ( $\mathrm{pH} 7.4,20 \mathrm{mM})$, the fluorescence recovery of P-DNA@1 $(50 \mathrm{nM} / 9 \mu \mathrm{M})$ sensor towards $\mathrm{Ag}^{+}$with different concentrations in Hepes buffer ( $\mathrm{pH} 7.4,20 \mathrm{mM})$, the fluorescence quenching of $1+$ ds-DNA@ $\mathrm{Ag}^{+}(9 \mu \mathrm{M} / 50 \mathrm{nM} / 6 \mu \mathrm{M})$ sensing system towards $\mathrm{S}^{2-}$ with different concentrations in Hepes buffer ( $\mathrm{pH} 7.4,20 \mathrm{mM}$ ), the fluorescence quenching of the P-DNA (50 nM) incubated with different concentrations of MOF 1 in different $\mathrm{pH}$ Hepes buffer solutions $(\mathrm{pH}=6.5,7.0,7.4)$, the fluorescence recovery of P-DNA@1 $(50 \mathrm{nM} / 9.0 \mu \mathrm{M})$ sensing system towards different concentrations of $\mathrm{Ag}^{+}$in different $\mathrm{pH}$ buffer solutions $(\mathrm{pH}=6.5,7.0$,

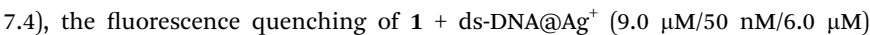
sensing system towards various concentrations of $\mathrm{S}^{2-}$ in different $\mathrm{pH}$ buffer solutions $(\mathrm{pH}=6.5,7.0,7.4)$, reference. CCDC 1892132. For ESI and crystallographic data in CIF or other electronic format see DOI: 10.1039/c9ra02028d

$\ddagger$ These authors contributed equally to this work.
However, the biological accumulation of $\mathrm{Ag}^{+}$raises serious concerns as a result of its relevance to multiple organ dysfunction syndrome, cytotoxicity, argyria and weakness of mitochondrial ability. ${ }^{2} \mathrm{Ag}^{+}$is accumulated via the water and food cycle, and thus a $0.5 \mu \mathrm{M}$ concentration up-limit of $\mathrm{Ag}^{+}$in drinking water is regulated by U.S. Environmental Protection Agency (US EPA) and World Health Organization (WHO). ${ }^{3}$

On the other hand, sulfide $\left(\mathrm{S}^{2-}\right)$ possesses an important biological function. ${ }^{4} \mathrm{~S}^{2-}$ exhibits a strong affinity toward proton to give hydrogen sulfide $\left(\mathrm{H}_{2} \mathrm{~S}\right)$, which is the third largest gas signal molecules. $\mathrm{H}_{2} \mathrm{~S}$ takes part in the course of atherosclerosis, myocardial contraction, nerve transmission and regulation of insulin secretion. ${ }^{5}$ Moreover, high concentrations of $\mathrm{H}_{2} \mathrm{~S}$ gives rise to diseases such as diabetes, ${ }^{6}$ hepatic sclerosis, ${ }^{7} \mathrm{Alz}-$ heimer's disease, ${ }^{8}$ and Down's syndrome. ${ }^{9}$

An equally important concern is the co-existence of $\mathrm{Ag}^{+}$and $\mathrm{S}^{2-}$ that would result in the formation of $\mathrm{Ag}_{2} \mathrm{~S}$ precipitates due to its extremely low solubility product constant of $\mathrm{Ag}_{2} \mathrm{~S}\left(K_{\mathrm{sp}}=\right.$ $6.3 \times 10^{-50}$, r.t.). $\mathrm{Ag}_{2} \mathrm{~S}$ particle formation is harmful to eyes, skin and respiratory system..$^{10}$ It would, therefore, be essential to develop a sensor that can simultaneously detect the presence of $\mathrm{Ag}^{+}$and $\mathrm{S}^{2-}$. Some hazardous ions can be monitored by fluorescence-based chemosensors as a result of their rapid detection speed, simple procedure, and high sensitivity. ${ }^{11}$ Among them, metal-organic frameworks (MOFs), consist of metal ions and various organic ligands, have shown great potential in sensing metal ions and small molecules due to their unique advantages such as diversity, porosity, stability, amenability toward further functionalization. ${ }^{12}$ However, sensors by integrating MOFs and bio-related species, such as DNA, remains relatively rare. ${ }^{13}$ 
Herein, we report the construction of a sensing system by hybridizing a three-dimensional (3D) Cu-based MOF $[\mathrm{Cu}(\mathrm{Cdcbp})(\text { bpea })]_{n} \quad$ (MOF 1, $\mathrm{H}_{3} \mathrm{CdcbpBr}=$ 3-carboxyl-(3,5dicarboxybenzyl)-pyridinium bromide, bpea $=1,2-\operatorname{di}(4-$ pyridinyl)ethane, Fig. 1a) and a single-stranded, carboxytetramethylrhodamine (TAMRA)-labeled C-rich probe DNA (ssDNA, P-DNA). The MOF and P-DNA are associated through $\pi-$ $\pi$ stacking, hydrogen bonding, and electrostatic interactions, and thereby quenches the TAMRA fluorescence of the latter (offstate) via a photo-induced electron transfer to eliminate the high background fluorescence (Fig. 1b). ${ }^{\mathbf{1 4}}$ The formed MOFDNA probe, denoted as P-DNA@1, is able to sense the presence of $\mathrm{Ag}^{+}$through the formation of $\mathrm{C}-\mathrm{Ag}^{+}-\mathrm{C}$ coordination bonds, yielding the double-stranded hairpin-like DNA, that is ds-DNA@Ag ${ }^{+}$duplex. $^{15}$ The much more rigid ds-DNA@ Ag $^{+}$ duplex formed is subsequently detached from the surface of MOF 1 with the recovery of the TAMRA fluorescence (on-state). When further adding $\mathrm{S}^{2-}$ to the above formed $1+\mathrm{ds}-\mathrm{DNA} @ \mathrm{Ag}^{+}$ mixture, $\mathrm{Ag}^{+}$was extracted from ds-DNA@ $\mathrm{Ag}^{+}$to form $\mathrm{Ag}_{2} \mathrm{~S}$ precipitates and the ds-DNA unwinded and converts back to PDNA, and resorbed by MOF 1 to quench the fluorescence again (off-state). Thus, the "off-on-off" fluorescent sensing system was successfully constructed to monitor $\mathrm{Ag}^{+}$and $\mathrm{S}^{2-}$ in succession. The computational investigation revealed that P-DNA bounds to MOF 1 more tightly through multiple $\pi-\pi$ stacking and hydrogen bonding interactions than ds-DNA@ $\mathrm{Ag}^{+}$.

\section{Experimental}

\section{General}

IR spectra were recorded on a Nicolet MagNa-IR 550 infrared spectrometer. Elemental analyses for $\mathrm{C}, \mathrm{H}$, and $\mathrm{N}$ were carried out with an EA1110 CHNS elemental analyzer. Powder X-ray diffraction (PXRD) spectra were obtained with a Rigaku D/ max2200/PC. The X-ray generated from a sealed $\mathrm{Cu}$ tube was monochromated by a graphite crystal and collimated by a $0.5 \mathrm{~mm}$ MONOCAP $(\lambda \mathrm{Cu}-\mathrm{K} \alpha=1.54178 \AA)$. The tube voltage and current were $40 \mathrm{kV}$ and $40 \mathrm{~mA}$, respectively. Fluorescence spectra were measured on a PE LS-55 fluorescence spectrophotometer.

The synthesis of amphoteric tricarboxylic acid ligand- $\mathrm{H}_{3}-$ CdcbpBr was based on our reported procedure. ${ }^{14 c}$ The TAMRAlabeled cytimidine-rich probe DNA sequence (P-DNA: 5'TAMRA-ACCTCTTCTCTTCATTTTTCAACACAACACCG-3 ${ }^{\prime}$ ) was purchased from Sangon Inc. and stored at $-20{ }^{\circ} \mathrm{C}$ for use, and at (a)
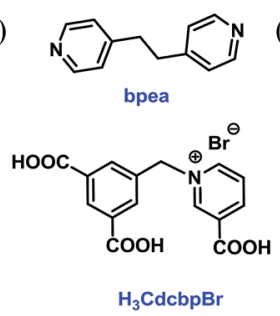

(b)

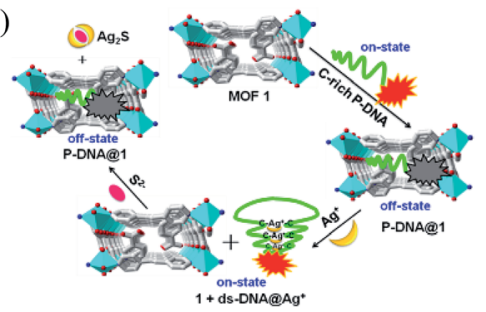

Fig. 1 (a) The structures of bpea and $\mathrm{H}_{3} \mathrm{CdcbpBr}$. (b) The detection mechanism of $\mathrm{Ag}^{+}$and $\mathrm{S}^{2-}$ based on the hybrid of MOF 1 and $\mathrm{C}$-rich $\mathrm{P}$ DNA.
$-80{ }^{\circ} \mathrm{C}$ for long-term preservation. All the other reagents and solvents were obtained from commercial sources and used without further purification.

\section{Synthesis of $[\mathrm{Cu}(\mathrm{Cdcbp})(\mathrm{bpea})]_{n}$ (1)}

Powder of $\mathrm{H}_{3} \mathrm{CdcbpBr}$ (764 mg, $2 \mathrm{mmol}$ ) was dispersed in distilled $\mathrm{H}_{2} \mathrm{O}(70 \mathrm{~mL})$ by sonication and the $\mathrm{pH}$ adjusted to 7.0 with $0.1 \mathrm{M} \mathrm{NaOH}$ to give a clear solution. This is followed by slow dropwise addition of $\mathrm{CuSO}_{4} \cdot 5 \mathrm{H}_{2} \mathrm{O}(391 \mathrm{mg}, 2 \mathrm{mmol})$ dissolved in $\mathrm{H}_{2} \mathrm{O}(20 \mathrm{~mL})$. The formed mixture was stirred for $30 \mathrm{~min}$ to give a clear blue solution. Subsequently, bpea (380 $\mathrm{mg}, 2 \mathrm{mmol}$ ) dissolved in DMF ( $5 \mathrm{~mL}$ ) was slowly added and the mixture was shaken for a while to give a blue solution containing a small amount of blue precipitate. Upon filtration, the filtrate was sub-packaged in thick-walled pressure bottle and transferred to a programmed oven. The temperature of the oven was smoothly increased from r.t. to $100{ }^{\circ} \mathrm{C}$ in $1 \mathrm{~h}$, maintained at $100{ }^{\circ} \mathrm{C}$ for $72 \mathrm{~h}$, before finally cooled to r.t. within $48 \mathrm{~h}$ to give blue block crystals. The crystals obtained were collected by filtration and washed with diethyl ether and dried in vacuo (910 mg, 83\%). Anal. calcd for $\mathrm{C}_{27} \mathrm{H}_{21} \mathrm{~N}_{3} \mathrm{O}_{6} \mathrm{Cu} \cdot \mathrm{H}_{2} \mathrm{O}$ : C $57.35 \%, \mathrm{H}$ 4.07\%, N 7.43\%; found: C 57.16\%, H 3.98\%, N 7.37\%. IR ( $\mathrm{KBr}$ disc, $\left.\mathrm{cm}^{-1}\right) \nu 3324(\mathrm{~s}), 3123(\mathrm{~m}), 1635(\mathrm{~s}), 1489(\mathrm{~m}), 1378(\mathrm{~s}), 1220$ (m), $1154(\mathrm{~m}), 1018(\mathrm{w}), 832(\mathrm{~m}), 815(\mathrm{~m}), 727(\mathrm{~m}), 614(\mathrm{~m}), 478$ (m).

\section{X-ray crystal structure determination}

Crystallographic measurements were made on a Bruker APEX II diffractometer by using graphite-monochromated Mo $\mathrm{K} \alpha(\lambda=$ $0.71073 \AA$ A) irradiation for MOF 1 . The data were corrected for Lorentz and polarization effects with the SMART suite of programs and for absorption effects with SADABS. ${ }^{16}$ All crystal structures were solved by direct methods and refined on $\mathrm{F}^{2}$ by full-matrix least-squares techniques with SHELXTL-97 program. ${ }^{17}$ The location of the two hydrogen atoms on the coordinated water was suggested by $\mathrm{Calc-OH}$ program in the WinGX suite ${ }^{\mathbf{1 8}}$ the water molecules were then refined as a rigid model with their thermal parameters constrained to $U_{\text {iso }}(\mathrm{H})=$ $1.2 U_{\text {eq }}(\mathrm{O})$. Spatially delocalized electron density in the lattice was found but acceptable refinement results could not be obtained for this electron density. The solvent contribution was then modeled using SQUEEZE in Platon. ${ }^{19}$ A summary of the key crystallographic data for $\mathbf{1}$ is listed in Table S1. $\dagger$

\section{Results and discussion}

\section{Characterization of MOF 1}

Single crystal X-ray diffraction analysis revealed that MOF 1 crystallizes in the monoclinic space group $C 2 / c$ and the asymmetric unit consists one $[\mathrm{Cu}(\mathrm{Cdcbp})($ bpea $)]$ molecule. As shown in Fig. 2a, each two $\mathrm{Cu}(\mathrm{II})$ ions are linked by a couple of $\mu-\mathrm{COO}^{-}$ $\left(\eta^{1}: \eta^{1}\right)$ groups from two Cdcbp ligands, and each $\mathrm{Cu}(\mathrm{II})$ ion further coordinated one chelating carboxylate to form a $\left[\mathrm{Cu}_{2}(-\right.$ Cdcbp) $)_{4}$ ] unit (Fig. 2a). Such unit extends to six equivalents to form a two-dimensional (2D) structure within the $b c$ plane as shown in Fig. 2b. These adjacent 2D layers have their associated 
(a)

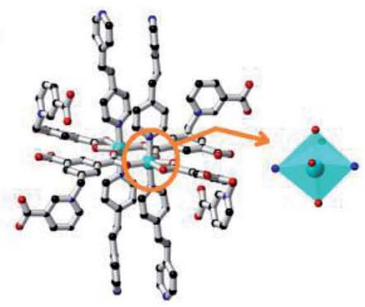

(b)

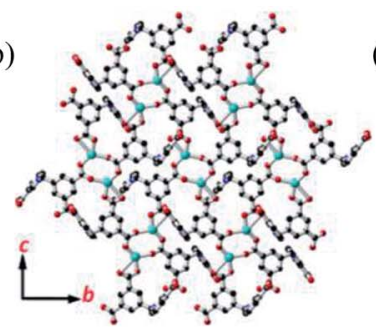

(c)

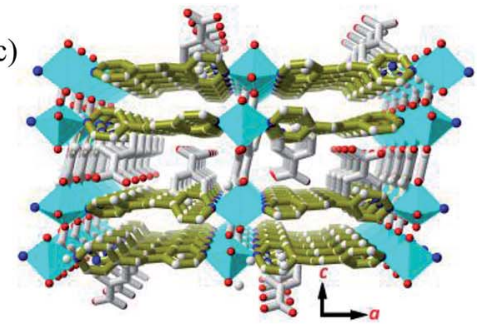

Fig. 2 The structure of MOF 1. (a) The coordination environment of $\mathrm{Cu}^{2+}$ in MOF 1. (b) The 2D plane sheet structure constructed by the $\left[\mathrm{Cu}_{2}(\mathrm{Cdcbp})_{4}\right]$ units. (c) The 3D structure of MOF 1. Color codes: $\mathrm{Cu}$ (turquoise), O (red), N (blue), C (black) and bpea (olive green).

benzoate oriented face-to-face and approximate 13.4 ̊̊apart, an ideal distance to further accommodate one bpea ligand $(13.4 \AA$ approximates the distance of one bpea ligand of $c a .9 .4 \AA$ and a pair of $\mathrm{Cu}-\mathrm{N}$ bonds with $c a .2 .0 \AA$ for each) (Table S2 $\dagger$ ). The $\mathrm{Cu}$-bpea association is aligned in the $a$ direction, completes the octahedral coordination geometry of $\mathrm{Cu}^{2+}$ (Fig. 2a), and result in a 3D network of MOF 1 as shown in Fig. 2c.

\section{$\mathrm{Ag}^{+}$detection with P-DNA@1 hybrid and $\mathrm{S}^{2-}$ detection with 1 + ds-DNA@Ag ${ }^{+}$system}

MOF 1 is water stable and its powder X-ray diffraction (PXRD) pattern indicated that the as-synthesized MOF 1 and its fresh powder immersed in Hepes buffer $(\mathrm{pH}=6.5,7.0,7.4)$ for $24 \mathrm{~h}$ matched very well with the simulated one, suggesting its phase purity and buffer stability (Fig. S1†). The scanning electron microscopic (SEM) images of the fresh MOF 1 gave the size of $831.25 \pm 80 \mathrm{~nm}$, further indicating its phase homogeneity (Fig. S2†).

In MOF 1, the Cdcbp and bpea ligands contain conjugated $\pi$ electron system, $\mathrm{Cu}^{2+}$, and quaternary ammonium groups, all facilitate its binding with ss-P-DNA molecules through a variety of weak intermolecular interactions, such as $\pi-\pi$ interactions and hydrogen bonding, and ultimately lead to fluorescence quenching. ${ }^{20}$ In order to verify our hypothesis, we first studied the stability of P-DNA in Hepes buffer at three different $\mathrm{pH}$ conditions $(6.5,7.0,7.4)$ that approximate the physiological conditions. As shown in Fig. $\mathrm{S} 3, \dagger$ the emission profile is retained in these condition in $4 \mathrm{~h}$. Then we studied the interaction of MOF 1 with P-DNA at these $\mathrm{pH}$ conditions to make the $\mathrm{Ag}^{+}$sensor. As shown in Fig. 3a, S4a and $\mathrm{S} 5 \mathrm{a}, \uparrow$ in all three conditions, the fluorescence intensity of P-DNA gradually decreased with the increasing concentration of MOF 1 up to 9.0 $\mu \mathrm{M}$ with a quenching efficiency $\left(Q_{\mathrm{E}}, \%\right)$ of $89.3 \%$ due to the formation of P-DNA@1 $\left(Q_{\mathrm{E}}=\left(F_{0}-F_{\mathrm{M}}\right) / F_{0} \times 100 \%\right.$, wherein $F_{\mathrm{M}}$ and $F_{0}$ are the fluorescent intensities at $582 \mathrm{~nm}$ in the presence and absence of MOF 1, respectively). Our second step involves the sensing of $\mathrm{Ag}^{+}$using P-DNA@1 also at three different $\mathrm{pH}$ conditions $(6.5,7.0,7.4)$. As shown in Fig. $3 b, S 4 b$ and $S 5 b, \dagger$ in all three conditions, when $\mathrm{Ag}^{+}$was added into the P-DNA@1 sensing system with gradually increasing concentrations, the fluorescence intensity recovered to saturation with a concentration of $\mathrm{Ag}^{+}$from 0 to $6.0 \mu \mathrm{M}$. The recovery efficiency $\left(R_{\mathrm{E}}\right)$ was 4.9 on the basis of $R_{\mathrm{E}}=\left(F_{\mathrm{T}}-F_{\mathrm{M}}\right) / F_{\mathrm{M}}\left(F_{\mathrm{T}}\right.$ and $F_{\mathrm{M}}$ are the fluorescence intensities at $582 \mathrm{~nm}$ with and without $\mathrm{Ag}^{+}$, respectively). The fluorescence recovery spectra exhibits a linear relationship with the concentration of $\mathrm{Ag}^{+}$(Fig. 4a), and a linear equation of $Y=212.559 X+91.532$ with a related coefficient $R^{2}=$ 0.9995 can be derived. The detecting limit (LOD) of $\mathrm{Ag}^{+}$was $3.8 \mathrm{nM}$ calculated from $3 \sigma /$ slope $(\sigma=$ standard deviation for 10 blank samples), which is much lower than the reported materials, such as tetraphenyl ethylene $(874 \mathrm{nM}),{ }^{21}$ carbon dots $(320$ $\mathrm{nM}){ }^{22}$ imidazole derivatives (101 nM) ${ }^{23}$ and comparable to gold nanoparticle $(7.3 \mathrm{nM})^{24}$ and g- $\mathrm{C}_{3} \mathrm{~N}_{4}$ nanosheets (4.2 nM) (Table $\mathrm{S} 3 \dagger) .{ }^{25}$ Our third experiment concerns the sensing of $\mathrm{S}^{2-}$ using the above formed $\mathbf{1}+\mathrm{ds}-\mathrm{DNA} @ \mathrm{Ag}^{+}$system at three different $\mathrm{pH}$ conditions $(6.5,7.0,7.4)$. As shown in Fig. $3 c, 4 c$ and $S 5 c, \dagger$ in all three conditions, when various concentrations of $\mathrm{S}^{2-}$ were added to the 1 + ds-DNA@ $\mathrm{Ag}^{+}$system, the fluorescence intensity gradually decreased to stabilization with a maximum $\mathrm{S}^{2-}$ consumption of $6.0 \mu \mathrm{M}\left(Q_{\mathrm{E}}\right.$ value being $\left.86.9 \%\right)$. The fluorescence quenching spectra of $\mathbf{1}+\mathrm{ds}-\mathrm{DNA} @ \mathrm{Ag}^{+}$, as depicted in Fig. 4b, also showed good linearity between fluorescence intensity and $\mathrm{S}^{2-}$ concentration with the linear equation of $Y=$ $-89.855 X+544.153\left(R^{2}=0.9978\right)$, giving an LOD value of $5.5 \mathrm{nM}$ for $\mathrm{S}^{2-}$. Such a value is much lower than some (a)

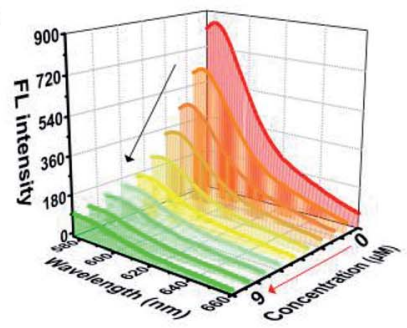

(b)

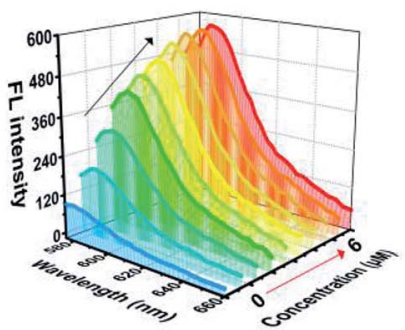

(c)

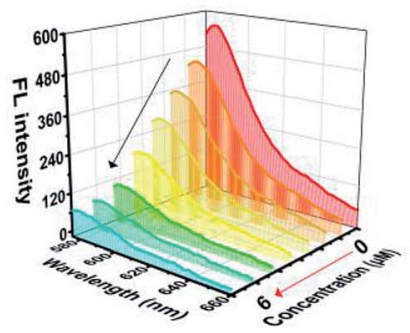

Fig. 3 (a) The fluorescence quenching of the P-DNA (50 nM) incubated with different concentrations of MOF 1. (b) The fluorescence recovery of P-DNA@1 $(50 \mathrm{nM} / 9.0 \mu \mathrm{M})$ sensing system towards different concentrations of $\mathrm{Ag}^{+}$. (c) The fluorescence quenching of $1+\mathrm{ds}-\mathrm{DNA} \mathrm{AAg}{ }^{+}(9.0 \mu \mathrm{M} /$ $50 \mathrm{nM} / 6.0 \mu \mathrm{M})$ sensing system towards various concentrations of $\mathrm{S}^{2-}$. 
(a)

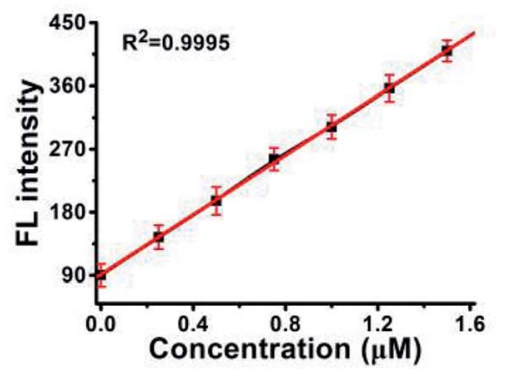

(b)

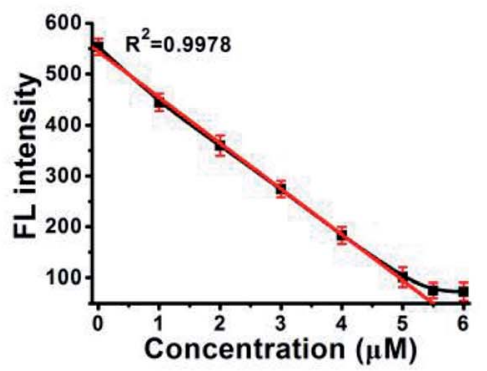

Fig. 4 A linear relationship between the fluorescence intensity of (a) P-DNA@1 at $582 \mathrm{~nm}$ and the concentrations of $\mathrm{Ag}^{+}$, (b) $1+\mathrm{ds}-\mathrm{DNA}\left(\mathrm{Ag}{ }^{+}\right.$at $582 \mathrm{~nm}$ and the concentrations $\mathrm{S}^{2-}$. Error bars represent the standard deviation for three measurements.

nanocomposite $(138 \mathrm{nM}),{ }^{26}$ gold nanoparticles $(80 \mathrm{nM}),{ }^{27}$ DNA@copper nanoparticles (80 nM) ${ }^{28}$ and nano Ag-carbon $(27$ $\mathrm{nM}$ ), ${ }^{29}$ and comparable to $\mathrm{g}-\mathrm{C}_{3} \mathrm{~N}_{4}$ nanosheets (3.5 nM) (Table $\mathrm{S} 4 \uparrow) .{ }^{25}$ All the results indicate that the detection process was not disturbed by the variation of the $\mathrm{pH}$ values.

\section{The selectivity of the sensor}

The anti-interference ability is another critical characteristic for the biosensors to ensure their practical application. Herein, the P-DNA was designed with specific bases that can pair with silver exclusively to form " $\mathrm{C}-\mathrm{Ag}^{+}-\mathrm{C}$ ". ${ }^{15}$ To further confirm our hypothesis, we carried the following experiments. First, different kinds of metal ions were used as interferences, including $\mathrm{Hg}^{2+}, \mathrm{Mn}^{2+}, \mathrm{Cd}^{2+}, \mathrm{Ca}^{2+}, \mathrm{Pb}^{2+}, \mathrm{Mg}^{2+}, \mathrm{Cu}^{2+}, \mathrm{Ba}^{2+}, \mathrm{Ni}^{2+}$, $\mathrm{K}^{+}, \mathrm{Na}^{+}, \mathrm{Zn}^{2+}, \mathrm{Cr}^{3+}, \mathrm{Co}^{2+}$ and $\mathrm{Fe}^{2+}$ with a concentration of $30 \mu \mathrm{M}$. As depicted in Fig. 5a, the biosensor of P-DNA@1 showed no remarkable response to these interfering metal ions. Subsequently, we added $\mathrm{Ag}^{+}(6.0 \mu \mathrm{M})$ to each of the above metal ion solutions, and the fluorescence intensities increased dramatically in contrast with other interfering metal ions with 5 -fold concentrations higher than that of $\mathrm{Ag}^{+}$. It is thus conclusive that the system had a high selectivity towards $\mathrm{Ag}^{+}$. Likewise, the specificity of the $\mathrm{S}^{2-}$ sensor was also evaluated by comparing its response to $\mathrm{S}^{2-}$ and other small anions $\left(\mathrm{HSO}_{4}{ }^{-}, \mathrm{SO}_{4}{ }^{2-}, \mathrm{OH}^{-}\right.$, $\mathrm{H}_{2} \mathrm{PO}_{4}{ }^{-}, \mathrm{CO}_{3}{ }^{2-}, \mathrm{NO}_{3}{ }^{-}, \mathrm{F}^{-}, \mathrm{Cl}^{-}, \mathrm{Br}^{-}$and $\mathrm{I}^{-}$) with a concentration of $30 \mu \mathrm{M}$ (5-fold higher than $\mathrm{S}^{2-}$ ). As illustrated in Fig. 5b, there was no obvious fluorescence intensity changes induced by other anions while the fluorescence intensity declined significantly when $\mathrm{S}^{2-}(6.0 \mu \mathrm{M})$ was presented. Thus, the interference of the other small anions to the biosensor $1+\mathrm{ds}-\mathrm{DNA} @ \mathrm{Ag}^{+}$was also negligible.
In order to further clarify the detection process, the conformational changes of the P-DNA induced by $\mathrm{Ag}^{+}$and $\mathrm{S}^{2-}$ were investigated by circular dichroism (CD) spectroscopy. Singlestranded P-DNA with a concentration of $5 \mu \mathrm{M}$ exhibited a strong positive CD peak at $278 \mathrm{~nm}$. As shown in Fig. 6a, the intensity of the peak gradually decreased with increased concentrations of MOF 1. MOF 1 fails to absorb all the P-DNA (5 $\mu \mathrm{M})$ at its highest concentration of $150 \mu \mathrm{M}$, and only lead to partial disappearance of the $\mathrm{CD}$ peak of P-DNA. With an increased concentration of $\mathrm{Ag}^{+}$in the P-DNA@1 sensing system, the intensity of positive peak weakened and ultimately disappeared, accompanied by the continuous intensity increase of the negative peak (Fig. 6b), attributable to the formation of a large amount of $\mathrm{C}-\mathrm{Ag}^{+}-\mathrm{C}$ ds-DNA@Ag ${ }^{+}$complex. ${ }^{30}$ Finally, with the addition of $\mathrm{S}^{2-}$ to the $\mathbf{1}+\mathrm{ds}-\mathrm{DNA} @ \mathrm{Ag}^{+}$system, the negative peak disappeared and the positive peak appeared again, indicating that the ds-DNA@ $\mathrm{Ag}^{+}$unwind to release PDNA (Fig. 6c).

\section{The detection mechanism}

In order to elucidate the detection mechanism, the binding free energy difference $(\Delta \Delta G)$ between reactions of MOF 1 with PDNA $\left(\Delta G_{\mathrm{P}-\mathrm{DNA} @ M O F}\right)$ and MOF 1 with ds-DNA@Ag ${ }^{+}\left(\Delta G_{\mathrm{MOF}+\mathrm{ds}-}\right.$ DNA@Ag') is calculated. The Gibbs free energy calculations were simplified by calculating single point energies. The result (Table $\mathrm{S} 5 \dagger$ ) showed that $\Delta \Delta G=-180.24 \mathrm{kcal} \mathrm{mol}^{-1}<0$, suggesting that P-DNA bounds to MOF 1 more tightly than ds-DNA@Ag ${ }^{+}$, corroborating the experimental observation.

The electrostatic surface showed that the surface of MOF 1 was largely positive and P-DNA covered by a negative and neutral surface with the scattered positive area, which led to (a)

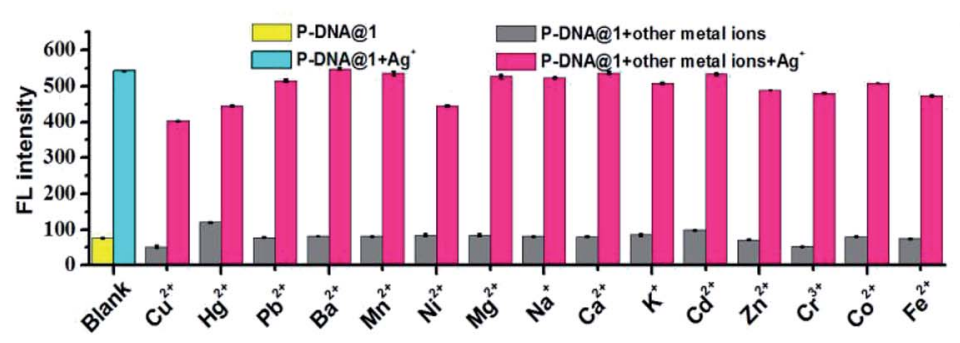

(b)

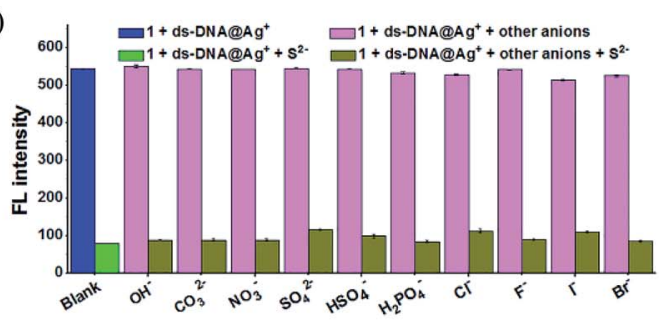

Fig. 5 (a) The detection selectivity of $\mathrm{Ag}^{+}$sensor (blank: P-DNA@1 (50 nM/9.0 $\mu \mathrm{M}$ ); $\mathrm{Ag}^{+}: 6.0 \mu \mathrm{M}$, other metal ions: $\left.30 \mu \mathrm{M}\right)$. (b) The detection selectivity of $\mathrm{S}^{2-}$ sensor (blank: $1+$ ds-DNA@Ag ${ }^{+}(9.0 \mu \mathrm{M} / 50 \mathrm{nM} / 6.0 \mu \mathrm{M}) ; \mathrm{S}^{2-}: 6.0 \mu \mathrm{M}$, other anions: $\left.30 \mu \mathrm{M}\right)$. Error bars represent the standard deviation for three measurements. 
(a)

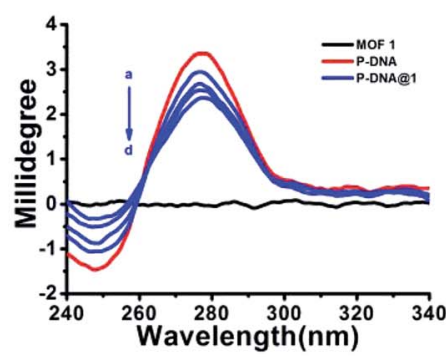

(b)

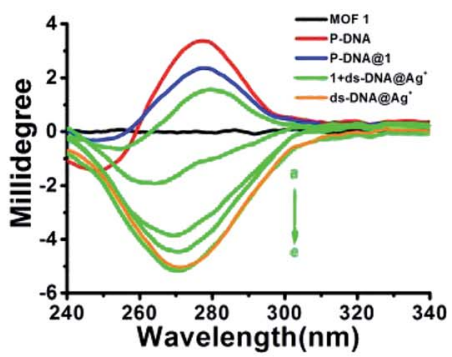

(c)

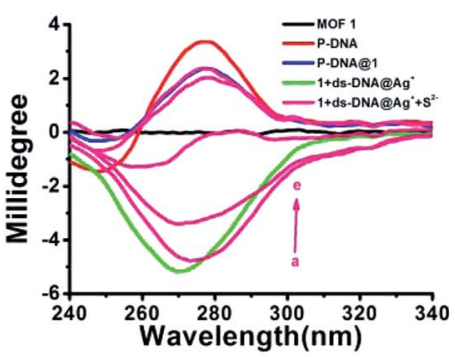

Fig. 6 (a) The CD spectra of MOF $1(150 \mu \mathrm{M})$ and P-DNA $(5 \mu \mathrm{M})$ with different concentrations of MOF 1 (50, 100, 125, 150 $\mu$ M, a-d). (b) The CD spectra of P-DNA@1 $(5 \mu \mathrm{M} / 150 \mu \mathrm{M})$ with different concentrations of $\mathrm{Ag}^{+}(12,24,36,48,60 \mu \mathrm{M}, \mathrm{a}-\mathrm{e})$ and ds-DNA@Ag ${ }^{+}(5 \mu \mathrm{M} / 60 \mu \mathrm{M})$. (c) The CD spectra of $1+$ ds-DNA@Ag ${ }^{+}(150 \mu \mathrm{M} / 5 \mu \mathrm{M} / 60 \mu \mathrm{M})$ with different concentrations of $\mathrm{S}^{2-}(20,40,60,80,100 \mu \mathrm{M}, \mathrm{a}-\mathrm{e})$.

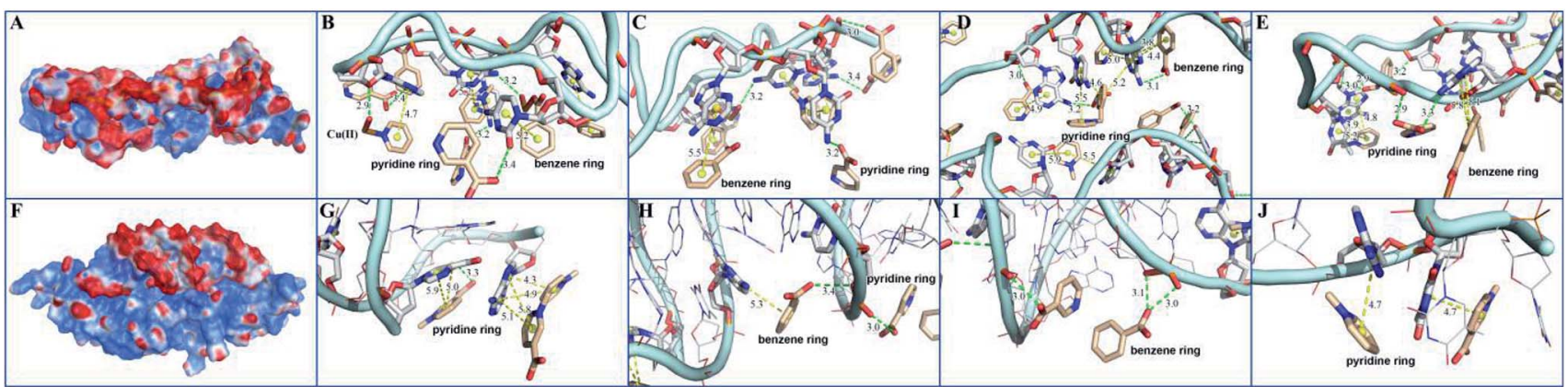

Fig. 7 The interactions between MOF 1 and P-DNA and ds-DNA@Ag ${ }^{+}(A)$ and $(F)$ showed the charge distributions where red area represented negative charges, blue positive, and white neutral; $(B-E)$ and $(G-J)$ showed the local binding modes for MOF 1 with P-DNA (B-E) and MOF 1 with ds-DNA@Ag ${ }^{+}(G-J)$, where MOF 1 was displayed by smudge lines and sticks, while P-DNA and ds-DNA@Ag ${ }^{+}$by light blue lines and sticks. Aromatic ring centers were denoted by yellow spheres, $\pi-\pi$ stacking, and hydrogen bonding interactions by yellow dashes and green dashes.

good electronic complement between MOF 1 and P-DNA. Single chain P-DNA exhibits a higher contact area with MOF 1 due to its structural flexibility (Fig. 7A), while double chain dsDNA@Ag ${ }^{+}$only has a small interface (Fig. 7F). MOF 1 bound to P-DNA mainly through $19 \pi-\pi$ stacking (Fig. 7B-E) between the aromatic rings in MOF 1 and nucleobases in P-DNA with the ring centroid distances in the range of 3.8-5.9 $\AA$. This is in addition to 18 hydrogen bonding (Fig. 7B-E) between the nucleobases in P-DNA and carboxylate groups in MOF 1, with the donor-acceptor distances in the range of 2.9-3.4 $\AA$. In sharp contrast, there are only $9 \pi-\pi$ stacking between the aromatic rings in MOF 1 and the nucleobases in ds-DNA@ $\mathrm{Ag}^{+}$, and 5 hydrogen-bondings between oxygen/nitrogen atoms of the phosphate group, or the nucleobases in ds-DNA@ $\mathrm{Ag}^{+}$and carboxylate groups in MOF 1 (Fig. 7G-J), with the ring centroid distances in the range of $4.2-5.8 \AA$ and donor-acceptor distances in the range of $2.8-3.5 \AA$.

\section{Detect $\mathbf{A g}^{+}$and $\mathrm{S}^{2-}$ in environmental water}

To further demonstrate the applications of these two biosensors, the recovery efficiencies of $\mathrm{Ag}^{+}$and $\mathrm{S}^{2-}$ were studied in three kinds of environmental water samples, including domestic water, lake water, and mineral water. The environmental water samples of $0.6 \mu \mathrm{M} \mathrm{Ag}^{+}$and $\mathrm{S}^{2-}$ were prepared from a condensed stock solution of silver ion $(10 \mathrm{mM})$ and sulfide ion $(10 \mathrm{mM})$, respectively. Both $\mathrm{Ag}^{+}$and $\mathrm{S}^{2-}$ in environmental water samples were measured as mentioned in the previous section. Each measurement was carried out three times repeatedly. As shown in Tables S6 and S7, $\uparrow$ the recovery efficiencies of the $\mathrm{Ag}^{+}$ and $\mathrm{S}^{2-}$ were calculated to be in the range of $98.2-101.8 \%$ with standard deviations (RSD) $\leq 1.0 \%$ for $\mathrm{Ag}^{+}$, and from $99.0 \%$ to $107.3 \%$ with RSD $\leq 4 \%$ for $\mathrm{S}^{2-}$, respectively. These results verified the reliability and practicability of the proposed fluorescence sensor for the successive detection of $\mathrm{Ag}^{+}$and $\mathrm{S}^{2-}$.

\section{Conclusions}

In summary, a highly sensitive and selective fluorescence sensor was created based on the Cu-MOF shielded with fluorescencelabeled C-rich ss-P-DNA for the specific and successive detection of $\mathrm{Ag}^{+}$and $\mathrm{S}^{2-}$ with a low detection limit of $3.8 \mathrm{nM}$ and $5.5 \mathrm{nM}$, respectively, which were two orders of magnitudes lower than those allowed in drinking water. The uniqueness of the present probe arises from the use of $\mathrm{C}-\mathrm{C}$ mismatched $\mathrm{P}$ DNA sequences 5'-TAMRA-ACCTCTTCTCTTCATTTTTCAACACAACACCG-3' $3^{\prime}$ that can exclusively recognize $\mathrm{Ag}^{+}$to form $\mathrm{C}-$ $\mathrm{Ag}(\mathrm{I})-\mathrm{C}$ duplex. ${ }^{15}$ The use of Cu-based MOF 1 as fluorescence quencher serves as an additional advantage as the $\mathrm{Ag}^{+}$sensing process is against a dark background. The sensing events are stable at three different $\mathrm{pH}$ conditions $(6.5,7.0,7.4)$ that mimicking physiological conditions, and are further transferrable to domestic, lake, and mineral waters, indicating the 
good adaptability of the present sensor. This discovery further inspired us to develop relevant sensors for the pairwise detection of other biologically relevant cations and anions, such as $\mathrm{Hg}^{2+}$ and $\mathrm{S}^{2-}, \mathrm{Pb}^{2+}$ and $\mathrm{Br}^{-}, \mathrm{Fe}^{3+}$ and ascorbic acid, and etc., using a shared mechanism and beyond.

\section{Conflicts of interest}

There are no conflicts to declare.

\section{Acknowledgements}

We are grateful for the financial support from the National Natural Science Foundation of China (21874064), the Natural Science Foundation from Guangdong Provincial Department of Science and Technology of China (2018A030313456) and One Belt One Road Incubation Project from Southern Medical University (YD2018N003). We also thank Dr Ziying Zhang from Guangzhou Yinfo Information Technology Co., Ltd. for doing the molecular simulation studies.

\section{Notes and references}

1 T. W. Purcell and J. J. Peters, Environ. Toxicol. Chem., 2010, 17, 539.

2 (a) S. Kim, J. E. Choi, J. Choi, K. H. Chung, K. Park, J. Yi and D. Y. Ryu, Toxicol. in Vitro, 2009, 23, 1076; (b) C. Greulich, D. Braun, A. Peetsch, J. Diendorf, B. Siebers, M. Epple and M. Koller, RSC Adv., 2012, 2, 6981; (c) B. Z. Zhang and C. Y. Wei, ChemistrySelect, 2017, 2, 6844.

3 (a) M. M. Hu, J. L. Fan, J. F. Cao, K. D. Song, H. Zhang, S. G. Sun and X. J. Peng, Analyst, 2012, 137, 2107; (b) Z. Y. Xiao, A. J. Tang, H. S. Huang and Z. Wang, Can. J. Chem., 2017, 95, 1267.

4 (a) S. A. Patwardhan and S. M. Abhyankar, Colourage, 1988, 35, 15; (b) R. Huang, X. Zheng and Y. Qu, Anal. Chim. Acta, 2007, 582, 267.

5 (a) E. Lowicka and J. Beltowski, Pharmacol. Rep., 2007, 59, 4; (b) J. W. Calvert, S. Jha, S. Gundewar, J. W. Elrod, A. Ramachandran, C. B. Pattillo, C. G. Kevil and D. J. Lefer, Circ. Res., 2009, 105, 365; (c) C. A. Wagner, J. Nephrol., 2009, 22, 173; (d) G. D. Yang, L. Y. Wu, B. Jiang, W. Yang, J. S. Qi, K. Cao, Q. H. Meng, A. K. Mustafa, W. T. Mu and S. M. Zhang, Science, 2009, 322, 587.

6 W. Yang, G. Yang, X. Jia, L. Wu and R. Wang, J. Physiol., 2005, $569,519$.

7 S. Fiorucci, E. Antonelli, A. Mencarelli, S. Orlandi, B. Renga, G. Rizzo, E. Distrutti, V. Shah and A. Morelli, Hepatology, 2005, 42, 539.

8 K. Eto, T. Asada, K. Arima, T. Makifuchi and H. Kimura, Biochem. Biophys. Res. Commun., 2002, 293, 1485.

9 P. Kamoun, M. C. Belardinelli, A. Chabli, K. Lallouchi and B. Chadefaux-Vekemans, Am. J. Med. Genet., Part A, 2003, 116, 310.

10 Y. Yin, W. Xu, Z. Tan, Y. Li, W. Wang, X. Guo, S. Yu, J. Liu and G. Jiang, Environ. Pollut., 2017, 220, 955.
11 (a) G. B. Demirel, B. Daglar and M. Bayindir, Chem. Commun., 2013, 49, 6140; (b) B. Gole, A. K. Bar and P. S. Mukherjee, Chem.-Eur. J., 2014, 20, 2276; (c) X. Y. Guo, F. Zhao, J. J. Liu, Z. L. Liu and Y. Q. Wang, J. Med. Chem., 2017, 5, 20035.

12 (a) L. Li, Q. Chen, Z. G. Niu, X. H. Zhou, T. Yang and W. Huang, J. Mater. Chem. C, 2016, 4, 1900; (b) A. M. Spokoyny, D. Kim, A. Sumrein and C. A. Mirkin, Chem. Soc. Rev., 2009, 40, 1218; (c) G. F. Ji, J. J. Liu, X. C. Gao, W. Sun, J. Z. Wang, S. L. Zhao and Z. L. Lin, J. Mater. Chem. A, 2017, 5, 10200; (d) D. Liu, J. P. Lang and B. F. Abrahams, J. Am. Chem. Soc., 2011, 133, 11042; (e) X. Y. Tang, J. X. Chen, G. F. Liu, Z. G. Ren, Y. Zhang and J. P. Lang, Eur. J. Inorg. Chem., 2008, 16, 2593; (f) F. L. Yuan, Y. Q. Yuan, M. Y. Chao, D. J. Young, W. H. Zhang and J. P. Lang, Inorg. Chem., 2017, 56, 6522; (g) Z. X. Zhang, N. N. Ding, W. H. Zhang, J. X. Chen, D. J. Young and T. S. A. Hor, Angew. Chem., Int. Ed., 2014, 53, 4628.

13 (a) H. Weng and B. Yan, Anal. Chim. Acta, 2017, 988, 89; (b) L. L. Wu, Z. Wang, S. N. Zhao, X. Meng, X. Z. Song, J. Feng, S. Y. Song and H. J. Zhang, Chem.-Eur. J., 2016, 22, 477; (c) P. P. Hu, N. Liu, K. Y. Wu, L. Y. Zhai, B. P. Xie, B. Sun, W. J. Duan, W. H. Zhang and J. X. Chen, Inorg. Chem., 2018, 57, 8382; (d) B. P. Xie, G. H. Qiu, B. Sun, Z. F. Yang, W. H. Zhang, J. X. Chen and Z. H. Jiang, Inorg. Chem. Front., 2019, 6, 148; (e) B. P. Xie, Q. H. Qiu, P. P. Hu, Z. Liang, Y. M. Liang, B. Sun, L. P. Bai, Z. H. Jiang and J. X. Chen, Sens. Actuators, B, 2018, 254C, 1133; $(f)$ G. H. Qiu, Z. H. Weng, P. P. Hu, W. J. Duan, B. P. Xie, B. Sun, X. Y. Tang and J. X. Chen, Talanta, 2018, 180, 396.

14 (a) S. P. Yang, W. Zhao, P. P. Hu, K. Y. Wu, Z. H. Jiang, L. P. Bai, M. M. Li and J. X. Chen, Inorg. Chem., 2017, 56, 14880; (b) H. Q. Zhao, G. H. Qiu, Z. Liang, M. M. Li, B. Sun, L. Qin, S. P. Yang, W. H. Chen and J. X. Chen, Anal. Chim. Acta, 2016, 922, 55; (c) H. Q. Zhao, S. P. Yang, N. N. Ding, L. Qin, G. H. Qiu, J. X. Chen, W. H. Zhang, W. H. Chen and T. S. A. Hor, Dalton Trans., 2016, 45, 5092.

15 A. Ono, S. Cao, H. Togashi, M. Tashiro, T. Fujimoto, T. Machinami, S. Oda, Y. Miyake, I. Okamoto and Y. Tanaka, Chem. Commun., 2008, 39, 4825.

16 G. M. Sheldrick, $S A D A B S$, Program for empirical absorption correction of area detector data, University of Göttingen: Göttingen, Germany, 1996.

17 G. M. Sheldrick, Acta Crystallogr., Sect. C: Struct. Chem., 2015, $71,3$.

18 L. J. Farrugia, J. Appl. Crystallogr., 1999, 32, 837.

19 A. L. Spek, J. Appl. Crystallogr., 2003, 36, 7.

20 (a) Z. W. Tang, H. Wu, J. R. Cort, G. W. Buchko, Y. Y. Zhang, Y. Y. Shao, I. A. Aksay, J. Liu and Y. H. Lin, Small, 2010, 6, 1205; (b) L. H. Tang, H. X. Chang, Y. Liu and J. H. Li, Adv. Funct. Mater., 2012, 22, 3083.

21 Y. Li, H. Yu, G. Shao and F. J. Gan, J. Photochem. Photobiol., A, 2015, 301, 14.

22 X. H. Gao, Y. Z. Lu, R. Z. Zhang, S. J. He, J. Ju, M. M. Liu, L. Li and W. Chen, J. Mater. Chem. C, 2015, 3, 2302. 
23 B. Zhao, Y. Xu, Y. Fang, L. Y. Wang and Q. G. Deng, Tetrahedron Lett., 2015, 56, 2460.

24 J. J. Du, H. Du and H. Y. Ge, Sens. Actuators, B, 2017, 4005, 31456.

25 S. Wang, D. Du, M. Yang, Q. Lu, R. Ye and X. Yan, Talanta, 2017, 168, 168.

26 T. Zhou, N. Wang, C. Li, H. Yuan and D. Xiao, Anal. Chem., 2010, 82, 1705.
27 H. H. Deng, S. H. Weng, S. L. Huang, L. N. Zhang, A. L. Liu and X. H. Lin, Anal. Chim. Acta, 2014, 852, 218.

28 J. Liu, J. H. Chen and Z. Y. Fang, Analyst, 2012, 137, 5502.

29 Z. X. Wang, C. L. Zheng, Q. L. Li and S. N. Ding, Analyst, 2014, 139, 1751.

30 S. Zhan, Y. Wu, L. Wang, X. Zhan and Z. Pei, Biosens. Bioelectron., 2016, 86, 353. 